\title{
Multi-scale analysis of hermatypic coral assemblages at Mexican Central Pacific
}

\author{
Joicye Hernández-Zulueta ${ }^{1,2}$, Fabián A. Rodríguez-Zaragoza ${ }^{2}$, Rubén Araya ${ }^{3}$, \\ Ofelia Vargas-Ponce ${ }^{4}$, Alma P. Rodríguez-Troncoso ${ }^{5}$, Amílcar L. Cupul-Magaña ${ }^{5}$, \\ Leopoldo Díaz-Pérez ${ }^{2}$, Eduardo Ríos-Jara ${ }^{2}$, Marco Ortiz ${ }^{3}$ \\ ${ }^{1}$ Programa de Doctorado en Ciencias en Biosistemática, Ecología y Manejo de Recursos Naturales y Agrícolas \\ (BEMARENA), Centro Universitario de Ciencias Biológicas y Agropecuarias, Universidad de Guadalajara. Camino \\ Ramón Padilla Sánchez No. 2100, Nextipac, Zapopan, Jalisco, CP 45110, México. \\ (JH-Z) E-mail: joicyehernandezzulueta@gmail.com. ORCID-iD: http://orcid.org/0000-0002-3147-7069 \\ ${ }^{2}$ Laboratorio de Ecosistemas Marinos y Acuicultura, Departamento de Ecología, Centro Universitario de Ciencias \\ Biológicas y Agropecuarias, Universidad de Guadalajara. Camino Ramón Padilla Sánchez No. 2100, Nextipac, Zapopan, \\ Jalisco, CP 45110, México. \\ (FAR-Z )(Corresponding author): rzf39259@ cucba.udg.mx. ORCID-iD: http://orcid.org/0000-0002-0066-4275 \\ (ERJ) E-mail: eduriosjara@ cucba.udg.mx. ORCID-iD: http://orcid.org/0000-0003-3534-6362 \\ (LDP) E-mail: leopoldo.diaz.p@gmail.com. ORCID-iD: http://orcid.org/0000-0003-0271-9257 \\ ${ }^{3}$ Instituto de Ciencias Naturales "Alexander Von Humboldt”, Instituto Antofagasta, Universidad de Antofagasta, P.O. Box \\ 170, Antofagasta, Chile. (RA) E-mail: ruben.araya@uantof.cl. ORCID-iD: http://orcid.org/0000-0002-2278-4198 \\ (MO) E-mail: marco.ortiz@uantof.cl. ORCID-iD: http://orcid.org/0000-0002-1126-7216 \\ ${ }^{4}$ Departamento de Botánica y Zoología, Centro Universitario de Ciencias Biológicas y Agropecuarias, Universidad de \\ Guadalajara. Camino Ramón Padilla Sánchez No. 2100, Nextipac, Zapopan, Jalisco, CP 45110, México. \\ (OV-P) E-mail: ovargas@ cucba.udg.mx. ORCID-iD: http://orcid.org/0000-0003-4139-503X \\ ${ }^{5}$ Laboratorio de Ecología Marina, Centro Universitario de la Costa, Universidad de Guadalajara. Av. Universidad 203, Del. \\ Ixtapa, Puerto Vallarta, Jalisco, CP 48280, México. \\ (APR-T) E-mail: pao.rodriguezt@gmail.com. ORCID-iD: http://orcid.org/0000-0001-6243-7679 \\ (ALC-M) E-mail: amilcar.cupul@ gmail.com. ORCID-iD: http://orcid.org/0000-0002-6455-1253
}

\begin{abstract}
Summary: The Mexican Central Pacific is located in a zone of oceanographic transition between two biogeographic provinces with particular conditions that affect the associated fauna. The objective of this study was to evaluate the variation of hermatypic coral assemblages in this region and to determine their relationship with the heterogeneity of the benthonic habitat and spatial variables. A total of 156 transects were carried out at 41 sites in the years 2010 and 2011 . The sampling effort returned $96.7 \%$ of the coral richness expected for the area, with a total of 15 species recorded. The results showed that richness, diversity and cover of corals varied only at the site and state scales. However, the composition and coverage of all coral species, as well as the benthonic habitat structure, differed significantly across the study scales (i.e. sites, zones and states). Canonical redundancy analysis showed that variation in the richness, diversity and assemblages of corals was explained by the cover of live corals, articulated calcareous algae, sandy substrate, sponges and fleshy macroalgae. This study suggests that local scale (i.e. site) variation in the coral assemblages of the Mexican Central Pacific is the result of the heterogeneity of the benthonic habitat, while geomorphological and oceanographic characteristics play a greater role at regional scale.
\end{abstract}

Keywords: hermatypic coral assemblages; spatial variation; community ecology; Mexican Central Pacific; benthonic habitat structure

\section{Análisis multiescala de las comunidades de coral hermatípico del Pacífico Central Mexicano}

Resumen: El Pacífico Central Mexicano se localiza en una zona de transición oceanográfica entre dos provincias biogeográficas con condiciones ambientales particulares que afectan la fauna asociada. El objetivo del estudio fue evaluar la variación de las comunidades de coral hermatípico de esta región y determinar su relación con la heterogeneidad del hábitat bentónico y variables espaciales. Se realizaron 156 transectos en 41 sitios en los años 2010 y 2011 . El esfuerzo de muestreo representó el $96.7 \%$ de la riqueza de coral esperada para el área, con un total de 15 especies registradas. Los resultados mostraron que la riqueza, diversidad y cobertura de corales variaron sólo en las escalas de sitio y de estado. En cambio, la composición y cobertura de todas las especies de coral, así como la estructura del hábitat bentónico, fueron significativamente diferentes en todas las escalas estudiadas (i.e. sitio, zona y estado). Los análisis de redundancia canónica mostraron que la variación de la riqueza, diversidad y de las comunidades de corales eran explicadas por la cobertura de coral vivo, algas calcáreas articuladas, sustrato arenoso, esponjas y macroalgas carnosas. Este trabajo sugiere que la variación de las comunidades de coral en el Pacífico Central Mexicano a escala local (i.e. sitio) se debe a la heterogeneidad del hábitat bentónico, mientras que a escala regional, las características geomorfológicas y oceanográficas desempeñan un papel más importante.

Palabras clave: comunidad de coral hermatípicos; variación espacial; ecología de comunidades; Pacífico Central Mexicano; estructura del hábitat bentónico 
Citation/Como citar este artículo: Hernández-Zulueta J., Rodríguez-Zaragoza F.A., Araya R., Vargas-Ponce O., RodríguezTroncoso A.P., Cupul-Magaña A.L., Díaz-Pérez L., Ríos-Jara E., Ortiz M. 2017. Multi-scale analysis of hermatypic coral assemblages at Mexican Central Pacific. Sci. Mar. 81(1): 91-102. doi: http://dx.doi.org/10.3989/scimar.04371.12A

Editor: J. Garrabou.

Received: November 12, 2015. Accepted: November 18, 2016. Published: January 10, 2017.

Copyright: @ 2017 CSIC. This is an open-access article distributed under the terms of the Creative Commons Attribution (CC-by) Spain 3.0 License.

\section{INTRODUCTION}

The coral ecosystems of the Mexican Pacific are currently considered among the most important of the Tropical Eastern Pacific, since they comprise more than 30 coral species (Glynn and Ault 2000, Reyes-Bonilla et al. 2010) developed as coastal reefs, reef patches and patch type communities with isolated colonies of corals (López-Pérez et al. 2012) of different species richness, cover, diversity and composition throughout the region (Reyes-Bonilla 2003). The coral assemblages of the Mexican Pacific are located southwest of the Gulf of California in Cabo Pulmo and San Gabriel (Reyes-Bonilla 2003), on the southern coast of Nayarit (Carriquiry and Reyes-Bonilla 1997) and the Islas Marías Archipelago (López-Pérez et al. 2016), Carrizales in Colima (Reyes-Bonilla et al. 2013), Ixtapa-Zihuatanejo in Guerrero (López-Pérez et al. 2012), Bahías de Huatulco National Park in Oaxaca (López-Pérez et al. 2014) and the oceanic Revillagigedo Archipelago (Ketchum and Reyes-Bonilla 1997). In general, the coral ecosystems of the Mexican Pacific are dominated by branching corals of the genus Pocillopora distributed in shallow waters and encrusting and sub-massive genera such as Porites and Pavona in deeper waters (e.g. Reyes-Bonilla 2003, Reyes-Bonilla et al. 2010).

In the Mexican Pacific, the highest richness and coverage of corals is found in the Mexican Central Pacific (Reyes-Bonilla 2003). This includes the coastal margin of the states of Nayarit, Jalisco, Colima and Michoacán, where approximately 15 species of corals have been recorded, showing variable cover values of up to $60 \%$ and mainly comprising pocilloporid species (Reyes-Bonilla et al. 2013). As in other regions of the world, the coral assemblage of the Mexican Central Pacific has been affected by El Niño Southern Oscillation (ENSO) events, with positive (El Niño) and negative (La Niña) thermal anomalies causing bleaching and massive mortality.

Recently, the condition and conservation status of the Mexican Pacific coral ecosystems were evaluated (Reyes-Bonilla et al. 2010, López-Pérez et al. 2012). Corals have been used as indicators of biodiversity and environmental health, since these organisms are ecosystem engineers that favour natural resilience (Bellwood et al. 2004). Corals are the main bioengineers of the reefs through their functionality (morphology of the colonies) and continuous accumulation of carbonates, by which they create tridimensional habitats for the associated fauna (Bellwood et al. 2004). Corals thus contribute to the heterogeneity of the benthonic habitat, increasing biodiversity by providing resources such as substrates, refuges, nurseries and food for associated vertebrates and invertebrates (Hermosillo-Nuñez et al. 2015, Rodríguez-Zaragoza and Arias-González 2015).

Detailed evaluations of the coral ecosystems of the Mexican Central Pacific are required in order to further our understanding of the relationship between the coral assemblages and habitat heterogeneity at different spatial scales, considering biogeographic position, status of protection and particular local characteristics. The objective of this study was therefore to evaluate the spatial variation of the Mexican Central Pacific coral assemblages and explore their relationship with structural elements of the habitat and other regional (i.e. geomorphological, oceanographic and biogeographic) processes at different spatial scales. This knowledge is important in order to propose new marine protected areas (MPAs) in the region of study, particularly on the coasts of southern Jalisco and Colima, where the coral ecosystems are currently unprotected.

\section{MATERIALS AND METHODS}

\section{Study area}

The study area includes $\sim 600 \mathrm{~km}$ of the Mexican Central Pacific coastline including four states: Nayarit to the north, Jalisco and Colima in the centre, and Michoacán to the south (Fig. 1). Geomorphologically, the Mexican Central Pacific has a narrow continental platform, broad areas of sandy and rocky beaches and areas with cliffs and protected bays that favour the discontinuous presence of coral ecosystems with different degrees of development: coral communities (i.e. isolated colonies), reef patches and coral reefs (ReyesBonilla 2003). Three oceanic currents converge in this region, each showing seasonal variations in magnitude (Wyrtki 1966). The California Current flows from the north during the winter season, bringing cold water of low salinity. From June to November, the Costa Rica (or Mexican) Current flows from Central America by southeast Mexico towards the Mexican Central Pacific, bringing warm waters of intermediate salinity. In contrast, the mass of water of the Gulf of California supplies warm water with high salinity (Kessler 2006). The convergence of these oceanic currents favours the presence of marine species from different biogeographic provinces of the Mexican Pacific (Spalding et al. 2007). Moreover, the incidence of upwelling zones, tropical storms and hurricanes, as well as ENSO events (Carriquiry et al. 2001), impacts and modifies the structure of coral ecosystems and their associated biodiversity. 

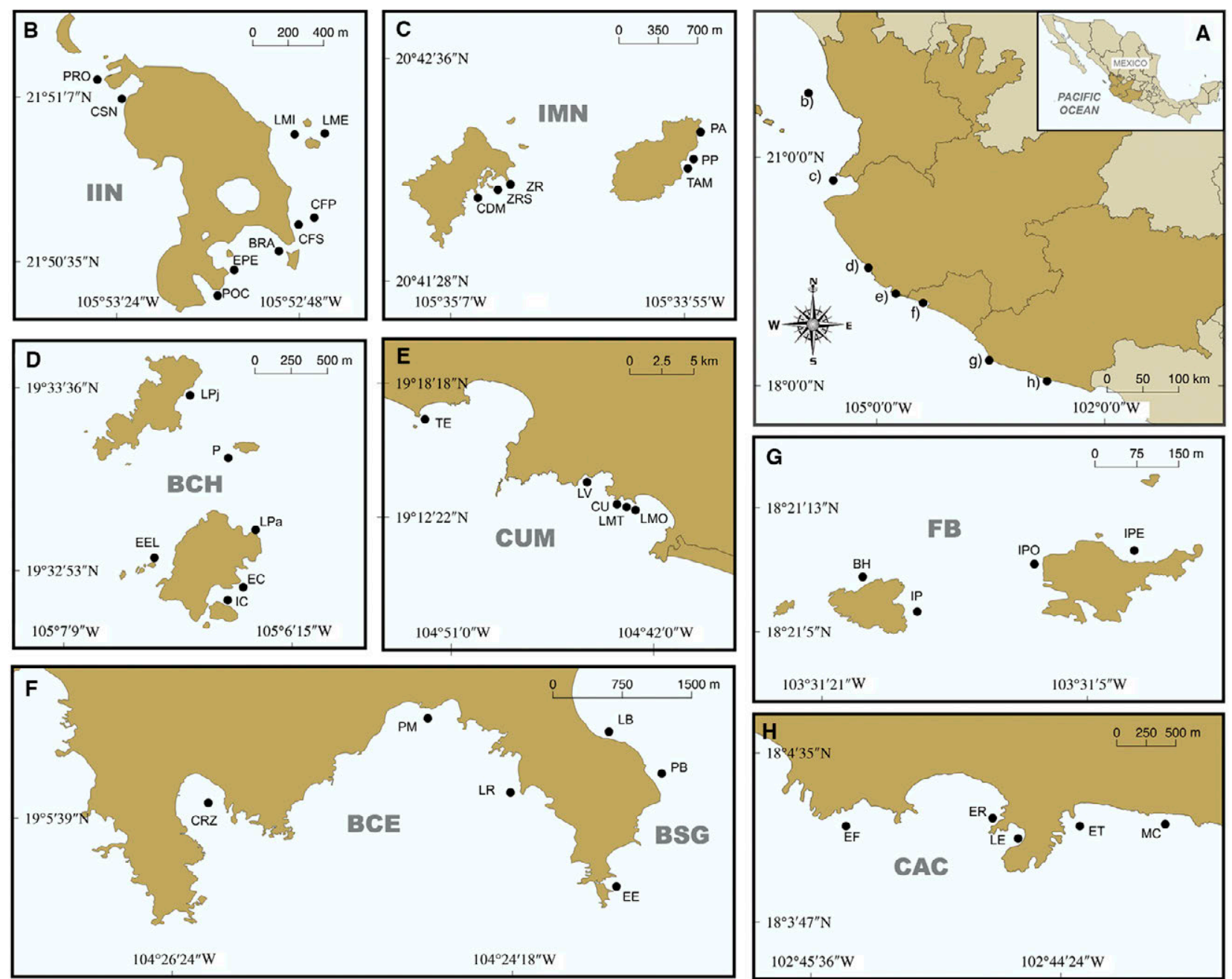

Fig. 1. - Study area location of the region in the Mexican Central Pacific (A), showing the hierarchical sampling design at the scale of states, zones and sites. B and C, correspond to Nayarit state: Isla Isabel zone (IIN) includes the sites Punta Rocosa (PRO), Caleta Sin Nombre (CSN), Las Monas Interno (LMI), Las Monas Externo (LME), Costa Fragata Somero (CFS), Costa Fragata Profundo (CFP), Bahía Rabijuncos (BRA), Ensenada de Pescadores (EPE) and Pocitas (POC). The Islas Marietas zone (IMN) includes the sites Playa del Amor (PA), Plataforma Pavonas (PP), Túnel Amarradero (TAM), Zona de Restauración (ZR), Zona de Restauración Sur (ZRS) and Cueva del Muerto (CDM). D and E, correspond to Jalisco state: Bahía Chamela zone (BCH) includes the sites Pelícanos (P), La Pajarera (Lpj), La Palma (Lpa), El Elefante (EEL), Ensenada Cocinas (EC), Isla Cocinas (IC); and Bahía Cuastecomates-Punta Melaque zone (CUM) includes the sites Tenacatita (TE), La Virgencita (LV), Cuastecomatito (CU), Las Monjas 1 (LMO) and Las Monjas 2 (LMT). F, corresponds to Colima state: Bahía Ceníceros zone (BCE) includes the sites Carrizales (CRZ), Paraíso Montemar (PM) and L'Recif (LR); and Bahía Santiago zone (BSG) includes the sites Elefante (EE), Punto B (PB) and La Boquita (LB). G and H, correspond to Michoacán state : (Faro de Bucerías) zone (FB) includes the sites Isla Pájaros Este (IPE), Barco Hundido (BH), Isla Pájaro Oeste (IPO) and Isla Protegida (IP); and Caleta de Campos zone (CAC) includes the sites El Relis (ER), El Faro (EF), La Ensenada (LE), El Teolan (ET) and Manto Carrizo (MC).

\section{Sampling strategy}

The sampling strategy comprised a nested hierarchical design including states $(>105 \mathrm{~km})$, zones $(1.5-10$ $\mathrm{km})$ and sites $(<0.1 \mathrm{~km})$. The state scale is affected by the geomorphological, oceanographic and biogeographic processes of the region, while local effects (e.g. those of habitat structure) operate at the site scale. At the zone scale, a synergy exists between regional and local effects. A total of 41 sites were sampled throughout the study area: 1) in Nayarit, nine sites in Isla Isabel and six in Islas Marietas; 2) in Jalisco, six in Bahía Chamela and five in Bahía Cuastecomate-Punta Melaque; 3) in Colima, three in Bahía Ceníceros and three in Bahía Santiago; 4) and in Michoacán, five in Faro de Bucerías and four in Caleta de Campos (Fig. 1).
Surveys were performed in 2010 and 2011 during the same climatic season (summer from June to September). In 2010, we sampled the sites belonging to the states of Jalisco, Colima and Michoacán, while those of Nayarit were sampled in 2011. However, this study only considered the spatial variation, since some states were sampled in different years. At each site, coral coverage was recorded in situ using five transects of length $25 \mathrm{~m}$ placed parallel to the coastline at depths of between 4 and $12 \mathrm{~m}$. Sampling strategy corrresponded to quadrats nested in line transects. Five quadrats (1 $\mathrm{m}^{2}$ ) were sampled per transect and these were evenly spaced at a distance of $5 \mathrm{~m}$. Likewise, in each quadrat, coverage of the different morphofunctional benthonic groups was estimated: soft corals, hydrocorals, turf, articulated and crustose calcareous algae, fleshy macroal- 
gae, sponges, barnacles, rubble, rock, sand and dead coral. All quadrats were considered pseudoreplicates, such that total coral richness and the coverages of coral species and morphofunctional benthonic groups were estimated as mean values per transect. The sampling effort was unbalanced at the site scale, with a total of 156 transects in the study area.

\section{Data analysis}

Sampling effort was evaluated with observed and expected species accumulation curves and the estimators Chao 1, Chao 2 and Jackknife 2 at the scale of state and Mexican Central Pacific, using 10000 randomizations without replacement in Estimates V9.1 (Colwell 2013). The structure of the assemblages of hermatypic coral was analysed with species richness (S), live coral cover (LCC) and Shannon diversity ( $\mathrm{H}^{\prime}$, decits) estimated at the scale of transect. Spatial variation in these attributes was evaluated with a geographic sampling design that considered the following factors: states (ST, 4 levels), zones (ZN, 8 levels) and sites (SI, 41 levels). This is expressed as

$$
\mathrm{Y}=\mu+\mathrm{ST}_{\mathrm{i}}+\mathrm{ZN}_{\mathrm{j}}\left(\mathrm{ST}_{\mathrm{i}}\right)+\mathrm{SI}_{\mathrm{k}}\left(\mathrm{ZN}_{\mathrm{j}}\left(\mathrm{ST}_{\mathrm{i}}\right)\right)+\varepsilon_{\mathrm{ijk}}
$$

where $\mathrm{Y}$ is the variable under analysis (i.e. S, LCC and $\left.\mathrm{H}^{\prime}\right), \mu$ is the mean of the analysed variable, and $\varepsilon$ is the accumulated error of the factors ST, ZN and SI. The factor ST considered the biogeographic eco-regions following the criteria of Spalding et al. (2007). The factor $\mathrm{ZN}$ corresponded to zones that have different environmental conditions and degrees of natural and human disturbance, while factor SI considered the 41 sampling sites. For this, a three-way fully nested analysis of variance (ANOVA) was performed based on permutations, and unbalanced at the scale of site. Site was considered a random factor, while the zones and states showed a fixed effect (model type III). The ANOVAs were constructed with matrices of Euclidean distance, following the criteria of Anderson et al. (2008). This non-restricted model was used because the data did not fit a Gaussian distribution and did not show homoscedasticity.

The spatial variation of the hermatypic coral assemblages (composition and abundance) and the structure of the benthonic habitat were analysed with permutational multivariate analysis of variance (PERMANOVA), following the previously described ANOVA design. This analysis was conducted with Bray-Curtis similarity matrices using square root-transformed data in order to reduce the contribution of the abundant species and increase that of the species of lower abundance (Clarke and Warwick 2001). The statistical significance of the ANOVAs and PERMANOVAs was tested with 9999 permutations under a reduced model and with the sum of squares type III (Anderson et al. 2008). The contributions of coral species per site, zone and state were estimated using similarity percentage analysis (SIMPER), performed with BrayCurtis similarity matrices using the same pre-treatment as that used in the PERMANOVA. These univariate and multivariate analyses were performed in Primer 6.1+PERMANOVA (Anderson et al. 2008).

The relationship between the coral assemblages and spatio-environmental variables was evaluated with additive partitions based on canonical redundancy analysis (RDA), with the relationship assumed to be linear. The biological variables corresponded to Y vectors constructed with species richness $(\mathrm{S})$ or Shannon diversity $\left(\mathrm{H}^{\prime}\right)$, as well as a $\mathrm{Y}$ matrix with the composition and cover of the coral species. The $\mathrm{X}$ matrices were constructed with environmental variables relating to variation in the corals, such as the cover values of live coral, soft corals, hydrocorals, turf, articulated and crustose calcareous algae, fleshy macroalgae, sponges, coral rubble, rock, sand and dead coral. The W matrix corresponded to the spatial variables obtained with a trend-surface analysis, based on geographic coordinates (latitude $=\mathrm{x}$, longitude $=\mathrm{y}$ ) transformed into UTM units and represented as a third-order polynomial ( $\mathrm{x}, \mathrm{y}, \mathrm{x}^{2}$, $\left.y^{2}, x^{3}, y^{3}, x y, x^{2} y, x^{2}\right)$ (Legendre and Legendre 1998). The RDA identified which $\mathrm{X}$ and $\mathrm{W}$ variables best explained the variation in $\mathrm{Y}$. The models were conducted at the site scale based on the results of the ANOVA and PERMANOVA, which evidenced that the site scale is where the greatest spatial variation exists. The Trace statistic was used to analyse the fit of the model, which represents the variation of $\mathrm{Y}$ explained by the canonical axes. The canonical additive partitions were conducted based on the criteria of Legendre and Legendre (1998), where the percentage of explained variation of community attributes $\left(\mathrm{S}\right.$ and $\left.\mathrm{H}^{\prime}\right)$ and coral assemblage structure was estimated using the following fractions: [a] is the pure environmental variation, or the influence of environmental variables in the structure of coral assemblages; [b] is the spatially structured environmental variation, or the effect of environmental variables in the spatial structure of the coral assemblages; [c] is the pure spatial variation that corresponds to the influence of spatial variables in the composition and coverage of corals; and [d] is the unexplained variation in the structure of the coral assemblages. In order to reduce the multi-colinearity among predictive variables, Pearson correlations ( $\mathrm{r}$ ) were used, eliminating those of $r \geq 0.90$. Likewise, a variance inflation factor (VIF) $\leq 10$ was used. Statistical significance was tested with 9999 permutations under a reduced model in CANOCO v4.5 (ter Braak and Šmilauer 2002).

\section{RESULTS}

\section{Coral assemblages}

A total of 15 species of hermatypic corals were recorded in the Mexican Central Pacific, belonging to four genera and four families. A total of 12 species were identified in the northern state of Nayarit, 9 and 11 in the central states of Jalisco and Colima, respectively, and 5 in the southern state of Michoacán (Supplementary Material, Table S1). Species richness, estimated with Chao 2 and Jackknife 2, showed a representativity of the observed species richness of $100 \%$ for Nayarit and Jalisco (Fig. 2A, B), 78.0\% in Colima (Fig. 2C) 

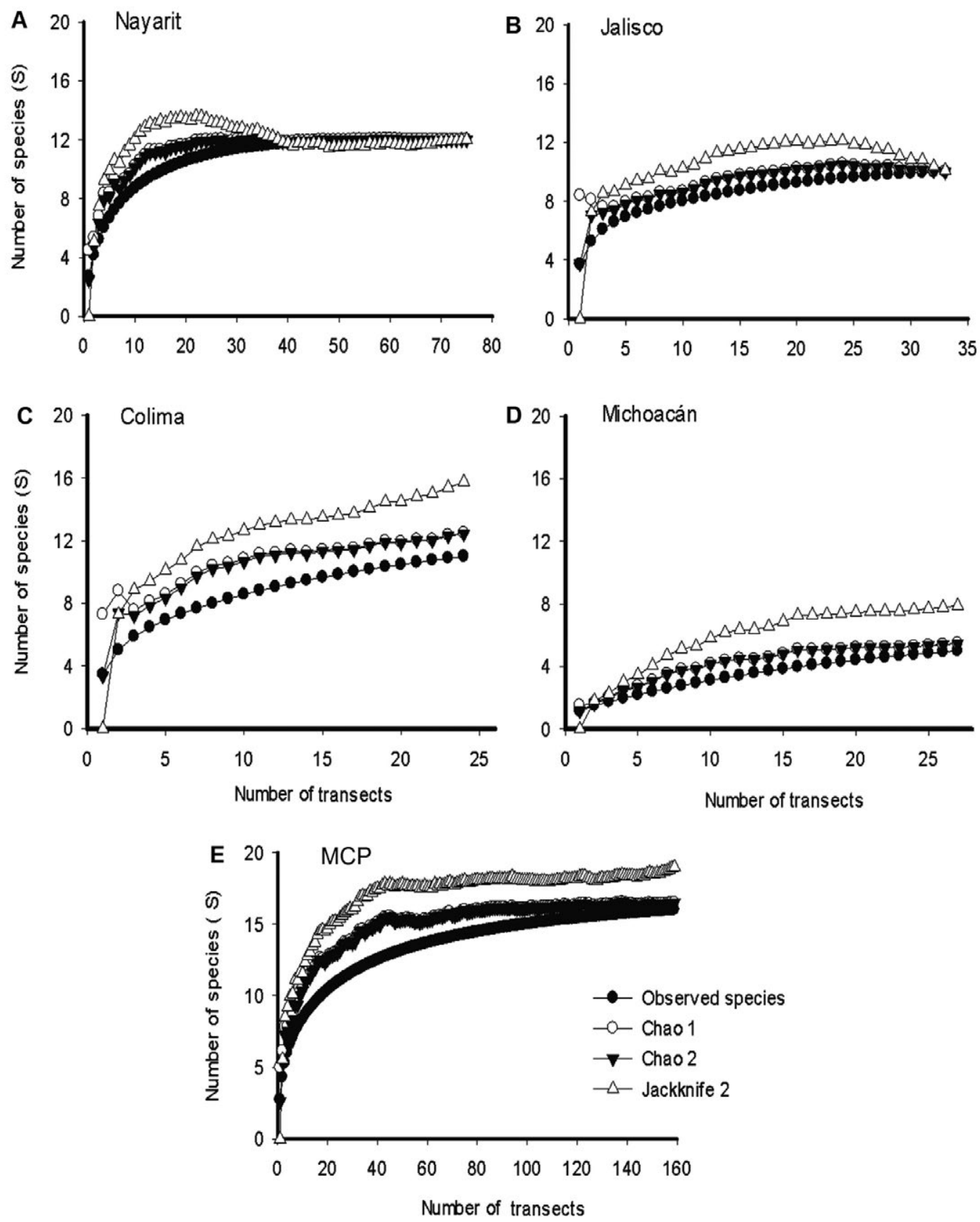

Fig. 2. - Observed and estimated coral species richness using Chao 1, Chao 2 and Jackknife 2 non-metric estimators at state and regional scale: (A) Nayarit, (B) Jalisco, (C) Colima, (D) Michoacán and (E) MCP (Mexican Central Pacific).

and $74.8 \%$ in Michoacán (Fig. 2D), as well as $96.7 \%$ for the entire Mexican Central Pacific (Fig. 2E).

Across the entire study area, the highest total species richness of corals was found at the sites of the central zone of the region (i.e. Jalisco and Colima), where Carrizales had 11 species and Cuastecomatito, Las Monjas 1 and Las Monjas 2 had 7 species each. The northern sites (i.e. Nayarit) Punta Rocosa, Las Monas Interno, Bahía Rabijuncos, Ensenada Pescadores each had 7 species. In contrast, the southern sites (i.e. Michoacán) Barco Hundido, Isla Pájaros Oeste, Isla Pájaros, Manto Carrizo, El Faro and El Relis, only had 1 species each. The zones with the highest total species richness were Isla Isabel
(12) in the northern part, followed by Bahía Ceníceros (11) and Bahía Chamela (8) in the central zone. The lowest richness was recorded in Faro de Bucerías and Caleta de Campos in the southern zone, with 4 species (Supplementary Material, Fig. S1, Table S1).

The most frequent species in the sites of the Mexican Central Pacific were Pocillopora verrucosa and Porites panamensis, which were observed at 32 of the 41 sites studied. The least frequent corals were Pavona gigantea at 8 sites, Pocillopora eydouxi at 5, Psammocora stellata and Psammocora superficialis at 4, Pavona duerdeni at 3 and Pocillopora effusus at 2. Pavona clavus, Pavona varians and Pocillopora inflata were 
Table 1. - Three-way fully nested ANOVA and PERMANOVA outputs to compare species richness (S), live coral cover (LCC), Shannon diversity $\left(\mathrm{H}^{\prime}\right)$, coral assemblage and habitat structure in the Mexican Central Pacific. Codes: ST, states; ZN, zones; SI, sites. Bold numbers correspond to a statistical significance $\mathrm{p}<0.05$.

\begin{tabular}{|c|c|c|c|c|c|c|c|}
\hline & Source & Pseudo-F & $\mathrm{P}($ perm $)$ & & Source & Pseudo-F & $\mathrm{P}($ perm $)$ \\
\hline \multicolumn{8}{|l|}{ ANOVA } \\
\hline \multirow[t]{3}{*}{ Species richness $(\mathrm{S})$} & ST & 6.0003 & 0.0038 & \multirow{6}{*}{$\begin{array}{l}\text { Shannon diversity } \\
\left(\mathrm{H}^{\prime}\right)\end{array}$} & ST & 22.998 & 0.0001 \\
\hline & ZN(ST) & 0.4917 & 0.7459 & & ZN(ST) & 0.36071 & 0.8348 \\
\hline & $\mathrm{SI}(\mathrm{ZN}(\mathrm{ST}))$ & 2.3957 & 0.0017 & & $\mathrm{SI}(\mathrm{ZN}(\mathrm{ST}))$ & 2.997 & 0.0002 \\
\hline Live coral cover & ST & 3.2391 & 0.0384 & & & & \\
\hline \multirow[t]{2}{*}{ (LCC) } & ZN(ST) & 1.4057 & 0.2513 & & & & \\
\hline & $\mathrm{SI}(\mathrm{ZN}(\mathrm{ST}))$ & 5.3919 & 0.0001 & & & & \\
\hline \multirow{4}{*}{$\begin{array}{l}\text { PERMANOVA } \\
\text { Coral assemblages }\end{array}$} & & & & \multirow{4}{*}{$\begin{array}{l}\text { Benthonic habitat } \\
\text { structure }\end{array}$} & & & \\
\hline & ST & 9.8113 & 0.0001 & & ST & 4.3896 & 0.0002 \\
\hline & ZN(ST) & 5.3396 & 0.0001 & & $\mathrm{ZN}(\mathrm{ST})$ & 1.9866 & 0.0224 \\
\hline & SI(ZN(ST)) & 3.756 & 0.0001 & & SI $(\mathrm{ZN}(\mathrm{ST}))$ & 6.7904 & 0.0001 \\
\hline
\end{tabular}

each found at a single site only (Supplementary Material, Table S1).

The results of the ANOVA showed that the average values of species richness (S) and Shannon diversity $\left(\mathrm{H}^{\prime}\right)$, as well as live coral cover (LCC), mainly varied at the scales of site and state (Table 1). The pairwise comparisons of the factor "state" revealed differences between the average species richness, Shannon diversity and live coral cover of the state of Michoacán in comparison with those estimated for the state of $\mathrm{Na}$ yarit and the states of Jalisco and Colima (Supplementary Material, Table S2). The sites with highest average species richness were Las Monjas 1 and Cuastecomatito in Jalisco, Carrizales in Colima and Punta Rocosa in Nayarit (Fig. 3A, B). However, at state scale, Jalisco had the highest average species richness (Fig. 3C). The sites with the greatest Shannon diversity were Punta Rocosa in Nayarit, and the central sites Ensenada Cocinas in Jalisco and Carrizales in Colima (Fig. 3D, E). At state scale, Jalisco also had the highest Shannon diversity (Fig. 3F). The sites with the greatest live coral cover were Tenacatita, Las Monjas 1, La Palma and Cuastecomatito in Jalisco, as well as Carrizales in Colima, all of the central portion (Fig. 3G, H). The state of Jalisco had, once again, the highest live coral cover (Fig. 3I).

The PERMANOVA showed significant spatial variation in the composition and abundance of corals at site, zone and state scales (Table 1). The pairwise comparisons of the factor "state" demonstrated differences among all of the states, except between the states of Colima and Jalisco; the factor "zone" showed differences only between the northern zones of Isla Isabel and Islas Marietas (Supplementary Material, Table S2). At state scale, the greatest dissimilarity was shown between the state of Michoacán and the state of Nayarit $(76.83 \%)$, and the least dissimilarity between the states of Colima and Jalisco (57.20\%) (Supplementary Material, Table S3). The most dissimilar zones were Isla Isabel and Islas Marietas in Nayarit $(71.03 \%)$ and the least dissimilar were Caleta de Campos and Faro de Bucerías in Michoacán (29.52\%) (Supplementary Material, Table S4). The SIMPER analysis showed a great number of comparisons at site scale, for which reason only those species with the greatest contribution to the dissimilarity among the sites of each zone were sampled (Supplementary Material, Table S5). In general, the corals that most contributed to species dissimilarity at the scale of the Mexican Central Pacific were $P$. verrucosa, $P$. damicornis, $P$. capitata, $P$. lobata and $P$. panamensis. In particular, $P$. verrucosa was the species that most strongly favoured dissimilarity among the zones and sites of Nayarit, $P$. damicornis in the states of Jalisco and Colima and $P$. panamensis in Michoacán.

\section{Habitat structure}

The PERMANOVA showed that habitat structure varied significantly at the site, zone and state scale (Table 1). In general, the sites Tenacatita, Las Monjas 1, Carrizales, La Palma and Cuastecomatito, located in the states of Jalisco and Colima, showed the highest values of live coral cover in the Mexican Central Pacific (Supplementary Material, Table S6). The sites with the least live coral cover were Costa Fragata Profundo in the northern area, Elefante in the central area and Isla Protegida in the southern area, while the highest cover of rock was found at the central site Islas Cocinas and the northern site Playa del Amor, corresponding to the presence of rocky reefs or rocky-sandy beaches (Supplementary Material, Table S6).

Sponges showed a greater coverage at the northern site Platform Pavonas and the central site Punto B. The highest cover of articulated calcareous algae was at the central sites Paraíso Montemar and Punto B, while crustose calcareous algae were more abundant at the central site L'Recif and the southern site Barco Hundido. Fleshy macroalgae showed greatest cover at the central sites Elefante and La Boquita and the southern site La Ensenada, while turf was greatest at the southern sites Barco Hundido and Isla Pájaros. Soft corals had the highest cover at the southern sites El Relis and El Teolan, while the hydrocorals were most abundant at the northern sites Las Monas Externo and Las Monas Interno. Barnacles were a structural element of the benthos that only showed a high cover at the central site Ensenada Cocinas. The highest cover of rubble and dead coral was recorded at the central site Pelícanos. Finally, the cover of sand was greatest at the northern site Túnel Amarradero, and at the southern sites Manto Carrizo and Isla Pájaros (Supplementary Material, Table S6).

At the zone scale, the pairwise comparisons showed that the habitat stucture differed only between the central zones Bahía Chamela and Bahía Cuas- 


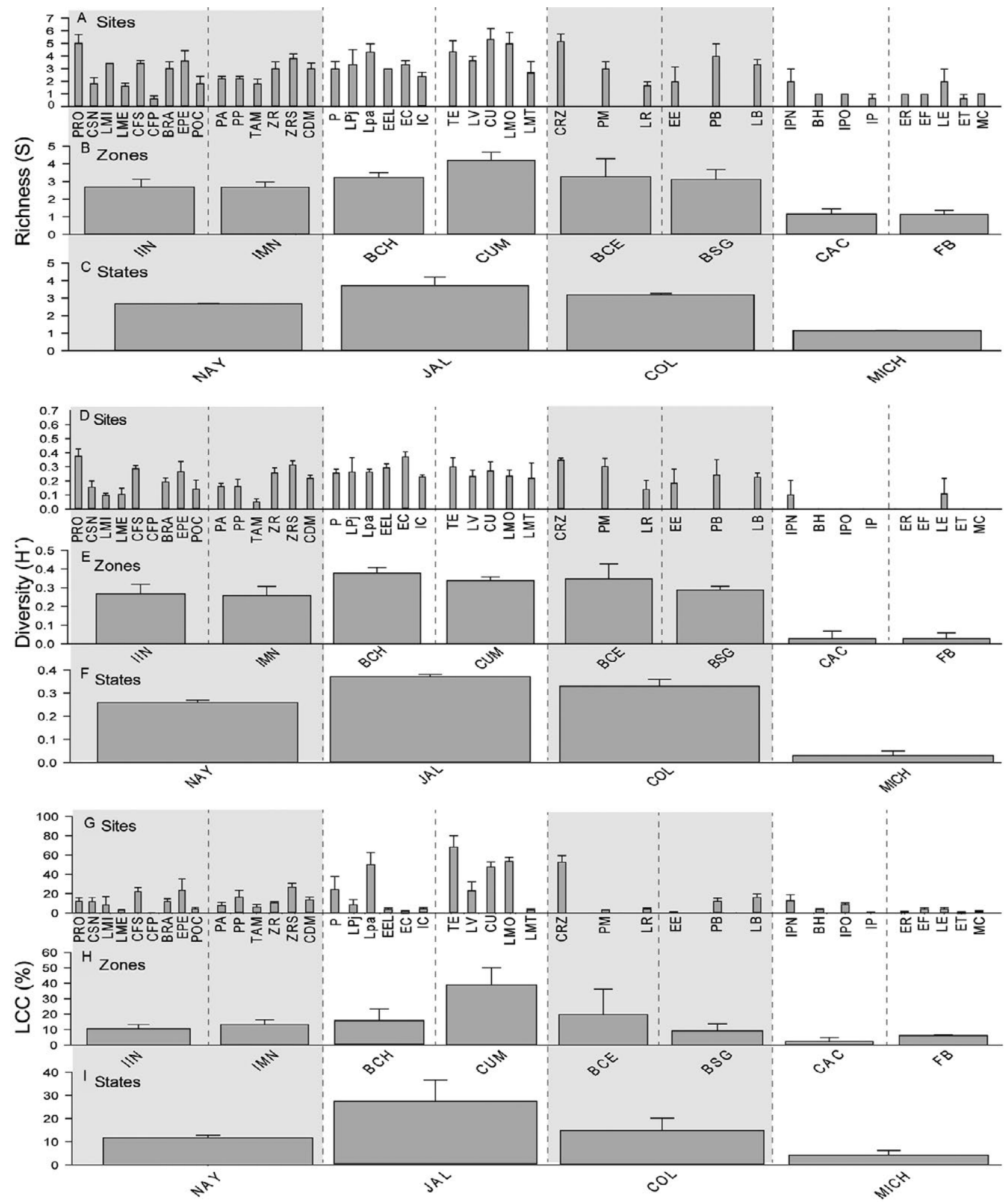

Fig. 3.- Species richness (S), Shannon diversity ( $\left.\mathrm{H}^{\prime}\right)$ and live coral (LCC) cover by sites, zones and states from Mexican Central Pacific. Abbreviations for sites, zones and states in Figure 1.

tecomate-Punta Melaque (Supplementary Material, Table S2). Bahía Cuastecomate-Punta Melaque and Bahía Ceníceros showed the highest live coral cover, while Bahía Santiago and Caleta de Campos showed the greatest cover of fleshy macroalgae. Turf was most abundant at Faro de Bucerías, Isla Isabel, Bahía Ceníceros and Islas Marietas. Rocky substrate had the greatest cover at Bahía Chamela and Islas Marietas, while sandy substrate dominated at Faro de Bucerías, Caleta de Campos, Isla Isabel and Islas Marietas. Crustose calcareous algae had the highest cover at Faro de Bucerías, Bahía Ceníceros and Caleta de Campos (Fig. $4 \mathrm{~A})$. Elements of the benthonic habitat with cover of $<10 \%$ are presented in Figure 4A. 


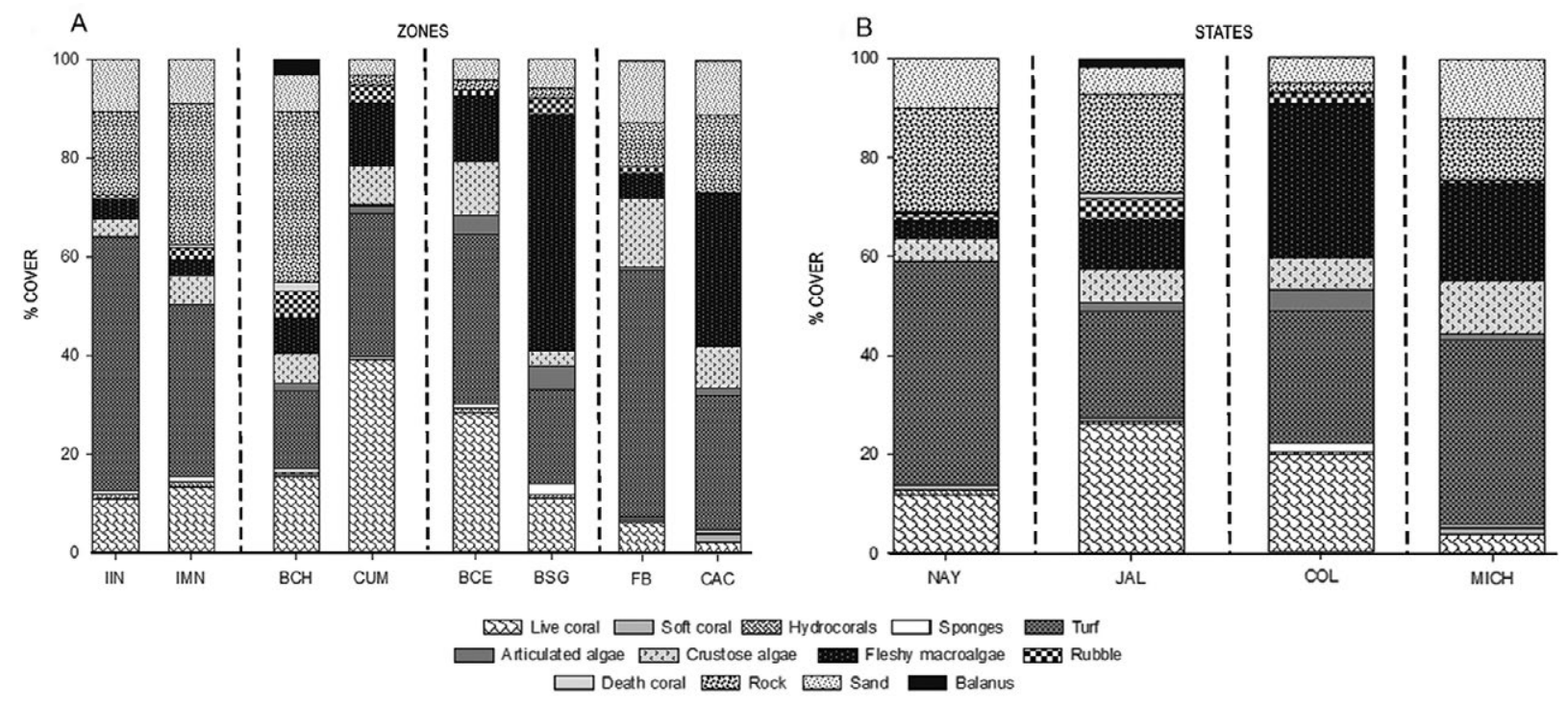

Fig. 4.- Average cover of benthonic morfofunctional groups for (A) zones and (B) states of Mexican Central Pacific. Abbreviations for zones and states in Figure 1.

Table 2. - Canonical additive partition of spatial variation of species richness, Shannon diversity and coral assemblage at site scale in the Mexican Central Pacific.

\begin{tabular}{|c|c|c|c|c|c|c|c|}
\hline & [a] & [b] & [c] & [d] & $\begin{array}{l}\text { Total Exp. Var. } \\
{[\mathrm{a}+\mathrm{b}+\mathrm{c}]}\end{array}$ & Env. Var. $[a+b]$ & Spat. Var. $[b+c]$ \\
\hline Species richness $(\mathrm{S})$ & 36.4 & 27.8 & 0.0 & 35.8 & \multicolumn{3}{|c|}{$\begin{array}{l}\text { Environmental variables: LCC, RSC, CCA, FMA and SS } \\
\text { Spatial variables: } x\end{array}$} \\
\hline Shannon diversity $\left(\mathrm{H}^{\prime}\right)$ & 29.9 & 15.4 & 0.0 & 54.8 & \begin{tabular}{l}
\multicolumn{1}{c}{45.2} \\
\multicolumn{1}{c}{$=\mathbf{0 . 0 0 1 0}$} \\
Environmental varia \\
Spatial variables: $\mathrm{x}$
\end{tabular} & $\begin{array}{c}45.2 \\
\mathrm{P}=\mathbf{0 . 0 0 1 0} \\
\text { les: } \mathbf{L C C}, \mathrm{RSC}, \mathrm{C}\end{array}$ & $\begin{array}{c}15.4 \\
\mathrm{P}=\mathbf{0 . 0 1 0 9} \\
\mathrm{A}, \text { FMA and SS }\end{array}$ \\
\hline Coral assemblage (composition and cover) & 45.3 & 23.0 & 0.0 & 31.5 & $\begin{array}{c}\mathbf{6 8 . 5} \\
\mathrm{P}=\mathbf{0 . 0 0 0 1} \\
\text { Environmental varia } \\
\text { Spatial variables: } \mathrm{x} \text { a }\end{array}$ & $\begin{array}{c}\quad 68.5 \\
P=\mathbf{0 . 0 0 0 1} \\
\text { les: } \\
\text { d } y\end{array}$ & $\begin{array}{c}23.0 \\
\mathrm{P}=\mathbf{0 . 0 0 0 5} \\
\mathrm{A}, \mathbf{F M A} \text { and SS }\end{array}$ \\
\hline
\end{tabular}

Notes: Hermatypic coral spatial diversity was represented by Y vectors (i.e. species richness and Shannon diversity) and Y matrices (i.e. coral species composition and cover). Environmental variables (Env. Var.) were included in X matrices, where LCC is live coral cover; RSC is sponge; CCA is crustose calcareous algae; FMA is fleshy macroalgae; SS is sand. W matrices corresponded to spatial variables (Spat. Var.), where $\mathrm{x}, \mathrm{y}, \mathrm{x}^{2}, \mathrm{y}^{2}, \mathrm{x}^{3}, \mathrm{y}^{3}, \mathrm{xy}, \mathrm{x}^{2} \mathrm{y}, \mathrm{xy}^{2}$ were derived from third-order polynomial terms of geographic coordinates represented as distances in metres. The total explained variation (Total Exp. Var.) was represented by $[\mathrm{a}+\mathrm{b}+\mathrm{c}]$ fraction, where $=[\mathrm{a}+\mathrm{b}+\mathrm{c}]=\mathrm{Y}$ vs. $\mathrm{X}$ and $\mathrm{W} ;[\mathrm{a}+\mathrm{b}]=$ Y vs. X; $[\mathrm{b}+\mathrm{c}]=\mathrm{Y}$ vs. W; $[\mathrm{a}]=$ pure environmental variation; $[\mathrm{b}]=$ spatially structured environmental variation; $[\mathrm{c}]=$ pure spatial variation; and $[\mathrm{d}]=$ unexplained variation. Bold numbers correspond to a statistical significance $\mathrm{p}<0.05$.

At the state scale, pairwise comparison showed that Nayarit has a habitat structure that differs from that of Jalisco and Colima, as well as from that of Michoacán (Supplementary Material, Table S2). Jalisco is characterized by the highest live coral cover of the Mexican Central Pacific and a high cover of rocky substrate. Nayarit showed the highest cover of rock and turf in the study area, as well as moderate cover of sandy substrate. In Michoacán, the lowest live coral cover was estimated, as well as a high cover of turf, sand and fleshy macroalgae. Finally, Colima had the highest cover of fleshy macroalgae and high live coral cover. Other benthonic elements with a cover of $<10 \%$ are shown in Figure 4B.

\section{Canonical additive partition}

The results of the canonical additive partitions showed that total species richness (S) and Shan- non diversity $\left(\mathrm{H}^{\prime}\right)$, as well as the composition and abundance of corals, were primarily explained by pure environmental variation [a] and secondarily by spatially structured environmental variation [b] at the studied Mexican Central Pacific sites. Pure spatial variation [c] did not make a significant contribution. The total variation explained by the RDA models $[\mathrm{a}+\mathrm{b}+\mathrm{c}]$ ranged from $45.2 \%$ to $68.5 \%$, with statistical significances of $0.0005<\mathrm{P}<0.011$ (Table $2)$. The environmental variables that best explained the spatial variation of species richness, Shannon diversity and the composition and abundance of hermatypic corals were live coral cover and coverage of sponges, crustose calcareous algae, fleshy macroalgae and sandy substrate. However, longitude and latitude (represented as $\mathrm{x}$ and $\mathrm{y}$, respectively) were the only significant spatial components in the RDA models (Table 2). 


\section{DISCUSSION}

The hermatypic coral assemblage structure of the Mexican Central Pacific varied significantly among the different spatial scales studied. At the regional (i.e. state) scale, the species richness and composition recorded were similar to those reported at other locations of the Mexican Pacific (Aguilar-Medrano and Calderón-Aguilera 2015) and Central America (Glynn et al. 2016). The region of the Mexican Central Pacific is considered one of the most important for its richness. The high number and composition of coral species can be explained by the oceanographic location in the inter-tropical zone of convergence, considered as one of transition, which generates mixed conditions of high variability throughout the year (López-Pérez et al. 2012). This favours high connectivity among the sites, promoting the dispersion of planulas between the biogeographical provinces of Corteziana and Mexicana (Glynn and Ault 2000) and thus allowing a greater overlap of species, as observed in the northern state of Nayarit and its respective zones and sites. This dispersion is also favoured by ENSO events, in which some larvae may be transported by the North Equatorial Countercurrent from the Revillagigedo Archipelago and the Clipperton Atoll (Glynn and Ault 2000, PazGarcía et al. 2012). For this reason, the Mexican Central Pacific functions as a gathering area of immigrant planulas from the Gulf of California (Reyes-Bonilla 2003), Central America and even the Indo-Pacific (Glynn and Ault 2000). Furthermore, differences in the sexual and asexual reproduction of the corals among the Mexican Pacific localities, coupled with local recruitment and oceanographic current patterns, promote high levels of species turnover that favour the presence of different coral fauna throughout the Tropical Eastern Pacific (Paz-García et al. 2012, Saavedra-Sotelo et al. 2013).

Richness, diversity, live coral cover and composition of coral assemblages are also affected by anthropogenic activities. Coral ecosystems in the Mexican Central Pacific are distributed in zones that have different degrees of natural and human disturbance (Reyes-Bonilla et al. 2002). Some are within the limits of national parks (e.g. Isla Isabel and Islas Marietas, Nayarit) with high live coral cover, while Bahía de Chamela in Jalisco has sanctuary status, but no management plan. The rest of the zones and sites of Jalisco, Colima and Michoacán have no protected status and most have both legal and illegal traditional fisheries. In addition to this, touristic recreational activities are conducted, especially at the Islas Marietas and some sites of Bahía Chamela and Bahía Santiago (Colima).

At the local scale, the coral assemblages varied significantly among sites, due probably to the fact that they have a discontinuous distribution and poor development generated, at least in part, by the following circumstances: (1) the continental platform of the Mexican Central Pacific is narrow and depths greater than $100 \mathrm{~m}$ are reached within short distances from the coast, affecting the temperature and illumination necessary for coral survival; and (2) the transparency of the water is seasonally very variable and occasion- ally low in the study area, which reduces the light and thus the photosynthetic activity of Symbiodinium sp. (Carriquiry and Reyes-Bonilla 1997). In addition, other environmental characteristics of the area, such as the presence of a large area of sandy coastline, salt marshes, estuaries, upwelling zones and riverine discharge, act to limit coral dispersion and colonization. Likewise, the heterogeneity of the habitat structure at each sampling site favours the presence of coral assemblages that differ among themselves, since each has a particular richness, composition, cover and diversity of species. Another factor that influences the coral composition in the bays and coves is protection against strong waves, wind and currents, which promotes the settlement, development and survival of coral larvae. The sites with the highest coral species richness are Carrizales, Las Monjas 1, Las Monjas 2 of the central states (i.e. Jalisco and Colima); and Punta Rocosa, Las Monas Interno, Bahía Rabijuncos and Ensenada Pescadores of the northern state (i.e. Nayarit), which all have specific geomorphological features that mitigate the stress of oceanographic conditions (e.g. strong waves, wind and currents).

The greatest total species richness of corals was recorded in Carrizales, Colima, where a true coral reef exists. This is one of the sites of greatest species richness in the Mexican Pacific, exceeding that of the largest and most developed reefs of southern Baja California (e.g. Cabo Pulmo, López-Pérez et al. 2012), Guerrero (e.g. Ixtapa, Aguilar-Medrano and Calderón-Aguilera 2015) and Oaxaca (e.g. Huatulco, López-Pérez et al. 2014). However, the species richness recorded in Carrizales was lower than that reported by Reyes-Bonilla et al. (2013), since $P$. stellata and $P$. contigua, which are of low cover and frequency, were not observed.

The estimated Shannon diversity at the sites with coral reefs and coral communities of the Mexican Central Pacific is low because of the high dominance of certain species within the assemblages. Pocillopora spp. dominate the coral assemblages because these branching corals compete more successfully than the massive species (i.e. Pavona and Porites) for space in shallower areas due to their faster growth rate (Reyes-Bonilla et al. 2013). In deeper waters, coral abundance is dominated by Pavona and Porites, which show slower growth with a lower capacity for asexual reproduction by fragmentation (Reyes-Bonilla 2003).

In the studied sites of the Mexican Central Pacific, four sites showed high values of live coral cover $(>47 \%)$, caused by the presence of abundant substrate (i.e. rocky substrate and coral reef matrix) for colonization by corals and stability of reef structures as well as a relative "stability" in oceanic temperature conditions. The live coral cover values estimated at Tenacatita, Carrizales, La Pajarera and Cuastecomatito, located in the central states (i.e. Jalisco and Colima), are considered among the highest in the Mexican Pacific, following the massive coral mortality event caused by the 1997-1998 ENSO (Reyes-Bonilla et al. 2002). However, they are similar to those reported in Ixtapa-Zihuatanejo, Guerrero (López-Pérez et al. 2012) and Carrizales, Colima (Reyes-Bonilla et al. 2013). 
In general, the coral assemblages of the Mexican Central Pacific showed higher values of species richness and live coral cover than those of Central and South American coral reefs (e.g. El Salvador, Nicaragua, Costa Rica, Panama, Colombia and Ecuador, Glynn et al. 2016), particularly in the case of the coral ecosystems located in the north and centre of the study area. These results are important in terms of updating the knowledge regarding coral assemblages in the Mexican Central Pacific, highlighting the importance of their species richness and live coral cover.

The coral species with the highest occurrence at the sampled sites of the Mexican Central Pacific were $P$. verrucosa and $P$. panamensis. The wide distribution of $P$. verrucosa could be due to its higher tolerance of thermic anomalies; the clade of its type D symbiont has considerable resistance to high temperatures and a capacity for recovery from photoinhibition caused by low temperatures (Rodríguez-Troncoso et al. 2014). The wide distribution of $P$. panamensis reflects its reproductive success and high tolerance of non-optimal conditions (Carpizo-Ituarte et al. 2011). This species therefore generates the coral ecosystems with the widest latitudinal distribution on the American Pacific coast (Glynn and Ault 2000).

The central states of Jalisco and Colima show the most similar coral assemblages. This similarity stems from the fact that both assemblages share geomorphological characteristics and a similar habitat structure. Furthermore, they show patches of coral with moderate live coral cover and fleshy macroalgae, as well as a low sandy substrate cover related to a greater contribution of $P$. damicornis, $P$. verrucosa and $P$. capita$t a$. In contrast, the coral assemblages of the northern state of Nayarit and the southern state of Michoacán were the most dissimilar. The sites of Nayarit showed a moderate live coral cover, which is essential for the development of the hermatypic corals. In Michoacán, however, low live coral cover was observed along with a moderate cover of sand, producing low topographical complexity that may have a direct effect on the structure of its coral assemblages, since coral recruitment depends on the availability of live coral cover and a rocky-calcareous substrate. Species composition in the state of Nayarit was dominated by $P$. verrucosa and $P$. damicornis, unlike the situation observed in the state of Michoacán, where $P$. panamensis dominated. The dissimilarities found at regional scale support the findings of previous studies (Aguilar-Medrano and Calderón-Aguilera 2015). Specifically, P. verrucosa is the most abundant coral in the northern portion of the Mexican Pacific (Reyes-Bonilla 2003), while $P$. damicornis is the main constituent of coral ecosystems in Oaxaca, in the southernmost region of the Mexican Pacific (López-Pérez et al. 2014) and in Central America (Glynn and Ault 2000).

The composition and cover of hermatypic coral species and of the structural elements of the habitat varied at the scales of site, zone and state. Variation at site and state scales may be a product of the local factors and regional processes described previously that influence the richness, diversity and cover of these species. Variation at zone scale may be the product of a combination of local effects (e.g. structural heterogeneity of the benthonic habitat in each site) and regional processes (biogeographic, oceanographic and coastal geomorphological) that act at the state scale. The canonical additive partitions showed that the fractions that explained the richness, diversity, cover and structure of the hermatypic coral assemblages of the Mexican Central Pacific were the pure environmental fraction [a] and the spatially structured environmental fraction $[\mathrm{b}]$. This finding shows that the coral assemblages are related to the elements of the benthonic habitat (i.e. fraction [a]) or covary with the spatial structure (i.e. fraction [b]) of the Mexican Central Pacific at the zone and state scales. This covariance at both scales could occur because of the influence of geomorphology, oceanographic patterns and the confluence of the biogeographic provinces of Corteziana and Mexicana. In general, the results of the canonical RDA showed that the live coral cover and crustose calcareous algae correlated best with the sites of greatest richness, diversity and cover of coral species. In contrast, high cover of sandy substrate, sponges and fleshy macroalgae is related to sites with a lower diversity and development of coral (Hermosillo-Nuñez et al. 2016).

The live coral cover allows the growth and recruitment of coral colonies (Sorokin 1993) and is a fundamental variable for the maintenance of biodiversity associated with coral ecosystems (Rodríguez-Zaragoza and Arias-González 2015). For their part, the crustose calcareous algae participate in the bioconstruction of reefs, increasing cementation through deposition of aragonite and calcite. These algae are also important for chemical detection of the substrate by the larvae and thus favour coral recruitment (Torres and Morelock 2002). In contrast, the fleshy macroalgae rapidly colonize the substrate and limit the growth and recruitment of corals. Despite being relatively weak competitors, their growth rate means that they can cover a large part of the reef in a relatively short period of time (Arias-González et al. 2008). They can also become tall and generate a shade effect on the corals, interrupting photosynthesis in their symbionts and causing abrasion damage to their tissues (McCook et al. 2001). The abundance of fleshy macroalgae can contribute to the reduction of hermatypic coral diversity in the Mexican Central Pacific. In addition, sponges compete aggressively with the corals for space; this competition involves both biological (structural and behavioural) and chemical (allelopathic) mechanisms that reduce coral cover (Castellanos et al. 2006). There are also some sponge species of the bioeroder type (e.g. Cliona vermifera) that can fragment the coral colonies and affect the growth and health of the corals (Carballo et al. 2008). Sand does not permit the recruitment and development of corals because it is an unstable substrate. For this reason, a high cover of sandy substrate is associated with small reefs, low live coral cover and poor topographical complexity (Rodríguez-Zaragoza and Arias-González 2015).

MPAs are currently recognized as a good management strategy that has proved useful for maintaining 
and promoting increased biodiversity (Mora et al. 2006). In addition, MPAs favour the regulation of ecosystem services such as fisheries and recreation areas (Bellwood et al. 2004). Despite their importance, the coral ecosystems of the Mexican Central Pacific have been subject to anthropogenic impact. For example, the sites of Punto B and La Boquita (which are located within the Bahía Santiago in Colima) are close to one of the largest commercial ports in the Mexican Pacific, which causes marine pollution, habitat destruction and changes in the local circulation patterns. There is also a densely populated city (Manzanillo) in the area with considerable urban development and tourism, which generates environmental impacts with possible irreversible consequences on marine ecosystems (Chávez-Comparán et al. 2008). This has an obvious impact on marine fauna and is perhaps one reason why this zone showed the lowest values of coral species richness. Meanwhile, the sites of the southern state of Michoacán also showed low values of coral richness, possibly due to the low heterogeneity of their habitats, as well as unregulated extractive activities (i.e. fishing), since no sites have protected status there. In order to protect the sites with important live coral cover, we therefore propose the establishment of MPAs that reflect the importance of these sites for both biodiversity and the economy.

\section{ACKNOWLEDGEMENTS}

We are indebted and grateful to all our colleagues in the "Arrecifes del Pacífico" group (www.mexlter.org. $\mathrm{mx}$ ), who have worked assiduously over many years collecting most of the data presented here. This work was partially funded by the Universidad de Guadalajara (P3E2010 and P3E2011 to F.A. Rodríguez-Zaragoza), PROMEP (103.5/08/2919 and 103.5/10/927 to F.A. Rodríguez-Zaragoza), CONABIO (HJ026 to L.E. Calderón-Aguilera), (PIFI-2010-14MSU0010Z-10 to A.L. Cupul-Magaña) and the authorities from Isla Isabel and Islas Marietas National Park. We also thank two anonymous reviewers for their comments and suggestions, wqhich increased the quality of this work. Finally, J. Hernández-Zulueta acknowledges the doctoral fellowship from CONACYT (0262538).

\section{REFERENCES}

Aguilar-Medrano R., Calderon-Aguilera L.E. 2015. Redundancy and diversity of functional reef fish groups of the Mexican Eastern Pacific. Mar. Ecol. 37: 119-133. https:/doi.org/10.1111/maec.12253

Anderson M.J., Gorely R.N., Clarke K.R. 2008. PERMANOVA+ Primer: Guide to Software and Statistical Methods. PRIMER-E Ltd, Plymouth, UK, 214 pp.

Arias-González J.E., Legendre P., Rodríguez-Zaragoza F.A. 2008. Scaling up beta diversity on Caribbean coral reefs. J. Exp. Mar. Biol. Ecol. 366: 28-36. https:/doi.org/10.1016/j.jembe.2008.07.035

Bellwood D.R., Hughes T.P., Folke C., et al. 2004. Confronting the coral reef crisis. Nature 429: 827-833. https:/doi.org/10.1038/nature02691

Carballo J.L., Bautista-Guerrero E., Leyte-Morales G.E. 2008. Boring sponges and the modeling of coral reefs in the east Pacific Ocean. Mar. Ecol. Prog. Ser. 356: 113-122. https:/doi.org/10.3354/meps07276
Carpizo-Ituarte E., Vizcaíno-Ochoa V., Chi-Barragán G., et al. 2011. Evidence of sexual reproduction in the hermatypic corals Pocillopora damicornis, Porites panamensis, and Pavona gigantea in Banderas Bay, Mexican Pacific. Cienc. Mar. 37: 97-112. https:/doi.org/10.7773/cm.v37i1.1773

Carriquiry J.D., Reyes-Bonilla H. 1997. Estructura de la comunidad y distribución geográfica de los arrecifes coralinos de Nayarit, Pacífico de México. Cienc. Mar. 23: 227-248.

Carriquiry J.D., Cupul-Magaña A.L., Rodríguez-Zaragoza F.A., et al. 2001. Coral bleaching and mortality in the Mexican Pacific during the 1997-98 El Niño and prediction from a remote sensing approach. Bull. Mar. Sci. 69: 237-249.

Castellanos L., Duque C., Zea S., et al. 2006. Isolation and Synthesis of (-)-(5S)-2-imino-1-methylpyrrolidine-5-carboxylic acid from Cliona tenuis: structure revision of pyrostatin. Org. Lett. 8: 4967-4970. https:/doi.org/10.1021/o1062087k

Chávez-Comparán J.C., Galeana-Lemus G.G., Manzo-Vargas I., et al. 2008. Catálogo de peces de arrecifes rocosos-coralinos de Punta Carrizales, Colima, México. Facultad de Ciencias Marinas, Universidad de Colima, $36 \mathrm{pp}$.

Clarke K.R., Warwick R.M. 2001. A further biodiversity index applicable to species lists: variation in taxonomic distinctness. Mar. Ecol. Prog. Ser. 216: 265-278. https:/doi.org/10.3354/meps216265

Colwell R.K. 2013. EstimateS: statistical estimation of species richness and share species from samples. Version 9.1. University of Connecticut, Storrs, USA. Available on line at: http://viceroy.eeb.uconn.edu/estimates

Glynn P.W., Ault J.S. 2000. A biogeographic analysis and review of the far eastern Pacific coral reef region. Coral Reefs 19: 1-23. https:/doi.org/10.1007/s003380050220

Glynn P.W., Alvarado J.J., Banks S., et al. 2016. Eastern Pacific Coral Reef Provinces, Coral Community Structure and Composition: An Overview. In: Glynn P.W., Manzello D.P., Enochs I.C. (eds), Coral Reefs of the Eastern Tropical Pacific: Persistence and Loss in a Dynamic Environment. Springer, pp. 107-176.

Hermosillo-Nuñez B., Rodríguez-Zaragoza F., Ortiz M., et al. 2015. Effect of habitat structure on the most frequent echinoderm species inhabiting coral reef communities at Isla Isabel National Park (Mexico). Community Ecol. 16: 125-134. https:/doi.org/10.1556/168.2015.16.1.14

Hermosillo-Nuñez B.B., Rodríguez-Zaragoza F.A., Ortiz M., et al. 2016. Influence of the coral reef assemblages on the spatial distribution of echinoderms in a gradient of human impacts along the tropical Mexican Pacific. Biodivers. Conserv. 25: 2137-2152. https:/doi.org/10.1007/s10531-016-1182-y

Kessler W.S. 2006. The circulation of the eastern tropical Pacific: a review. Prog. Oceanogr. 69: 181-217. https:/doi.org/10.1016/j.pocean.2006.03.009

Ketchum J.T., Reyes-Bonilla H. 1997. Biogeography of hermatypic corals from the Revillagigedo Archipelago, Mexico. Proceed. 8th Inter. Coral Reef Symp. Panama 1: 471-476.

Legendre P., Legendre L. 1998. Numerical ecology. Elsevier, Amsterdam.

López-Pérez R.A., Calderón-Aguilera L.E., Reyes-Bonilla H., et al. 2012. Coral communities and reefs from Guerrero, Southern Mexican Pacific. Mar. Ecol. 33: 407-416. https:/doi.org/10.1111/j.1439-0485.2011.00505.x

López-Pérez A., Granja-Fernández R., Aparicio-Cid C., et al. 2014. Corales pétreos, equinodermos y peces asociados a comunidades y arrecifes coralinos del Parque Nacional Huatulco, Pacífico sur mexicano. Rev. Mex. Biodiv. 85: 1145-1159. https:/doi.org/10.7550/rmb.43848

López-Pérez R.A., Cupul-Magaña A.L., Ahumada-Sempoal M.A., et al. 2016. The coral communities of the Islas Marias archipelago, Mexico: structure and biogeographic relevance to the Eastern Pacific. Mar. Ecol. 37: 679-690. https:/doi.org/10.1111/maec.12337

McCook L.J., Jompa J., Díaz-Pulido G. 2001. Competition between corals and algae on coral reefs: a review of evidence and mechanisms. Coral Reefs 19: 400-417. https:/doi.org/10.1007/s003380000129

Mora C., Andrefouret S., Costello M.J., et al. 2006. Coral reefs and the global network of marine protected areas. Science 312: 1750-1751. https:/doi.org/10.1126/science.1125295 
102 - J. Hernández-Zulueta et al.

Paz-García D.A., Chávez-Romo H.E., Correa-Sandoval F., et al. 2012. Genetic Connectivity Patterns of Corals Pocillopora damicornis and Porites panamensis (Anthozoa: Scleractinia) along the West Coast of Mexico. Pac. Sci. 66: 43-61. https:/doi.org/10.2984/66.1.3

Reyes-Bonilla H. 2003. Coral reefs of the Pacific coast of Mexico. In: Cortés J. (ed.) Latin American Coral Reefs. Elsevier, Amsterdam, pp. 331-349. https:/doi.org/10.1016/B978-044451388-5/50015-1

Reyes-Bonilla H., Carriquiry J.D., Leyte-Morales G.E., et al. 2002. Effects of the El Niño Southern Oscillation and anti El Niño event (1997-1999) on coral reefs of the western coast of México. Coral Reefs 21: 368-372.

Reyes-Bonilla H., Calderón-Aguilera L.E., Cruz-Piñón G., et al. 2010. Evaluación de la diversidad gama de corales arrecifales (Scleractinia) en el Pacífico de México. Rev. Mex. Biodiv. 81: 113-121.

Reyes-Bonilla H., Escobosa-González L., Cupul-Magaña A.L., et al. 2013. Community structure of zooxanthellate corals (Anthozoa: Scleractinia) in Carrizales coral reef, Pacific coast, Mexico. Rev. Biol. Trop. 61: 583-594. https:/doi.org/10.15517/rbt.v61i2.11161

Rodríguez-Troncoso A.P., Carpizo-Ituarte E., Pettay D.T., et al. 2014. The effects of an abnormal decrease in temperature on the Eastern Pacific reef building coral Pocillopora verrucosa. Mar. Biol. 161: 131-139. https:/doi.org/10.1007/s00227-013-2322-5

Rodríguez-Zaragoza F.A., Arias-González J.E. 2015. Coral biodiversity and bio-construction in the northern sector of the Mesoamerican reef system. Front. Mar. Sci. 2: 13. https:/doi.org/10.3389/fmars.2015.00013

Saavedra-Sotelo N.C., Calderón-Aguilera L.E., Reyes-Bonilla R.A., et al. 2013. Testing the genetic predictions of a biogeographical model in a dominant endemic Eastern Pacific coral (Porites panamensis) using a genetic seascape approach. Ecol. Evol. 3: 4070-4091. https:/doi.org/10.1002/ece3.734

Sorokin Y.I. 1993. Coral reef ecology. Springer, Heidelberg. https:/doi.org/10.1007/978-3-642-80046-7

Spalding M.D., Fox H.E., Allen G.R., et al. 2007. Marine ecoregions of the world: a bioregionalization of coastal and shelf areas. BioScience 57: 573-582.

https:/doi.org/10.1641/B570707 ter Braak C.J.F., Šmilauer P. 2002. CANOCO Reference Manual and CanoDraw for Windows User's Guide: Software for Canonical Community Ordination (version 4.5). Microcomputer Power, Ithaca NY, USA, 500 pp.

Torres J.L., Morelock J. 2002. Effect of terrigenous sediment influx on coral cover and linear extension rates of three caribbean massive coral species. Carib. J. Sci. 38: 222-229.

Wyrtki K. 1966. Oceanography of the eastern equatorial Pacific Ocean. Oceanogr. Mar. Biol. Annu. Rev. 4: 33-68.

\section{SUPPLEMENTARY MATERIAL}

The following material is available through the online version of this article and at the following link:

http://scimar.icm.csic.es/scimar/supplm/sm04371esm.pdf

Figure S1. - Latitude of the different zones of the Mexican Central Pacific with their coral species richness.

Table S1. - Richness and coverages (\%) of hermatypic corals species in the different sampling sites of the Mexican Central Pacific.

Table S2. - Results of the ANOVA and PERMANOVA pairwise test.

Table S3. - Results of the similarity percentage analysis (SIMPER) and coverages $(\%)$ of coral species by state. For SIMPER, only those species contributing $90 \%$ of the average dissimilarity (Ave. Dis.) of coral species between states of the Mexican Central Pacific are presented.

Table S4. - Results of the similarity percentage analysis (SIMPER) and coverages $(\%)$ of coral species per zone. For SIMPER, only those species contributing $90 \%$ of the average dissimilarity (Ave. Dis.) of coral species between zones of the Mexican Central Pacific are presented.

Table S5. - Results of the similarity percentage analysis (SIMPER) and coverages $(\%)$ of coral species per site. For SIMPER, only those species contributing $90 \%$ of the average dissimilarity (Ave. Dis.) of coral species between sampling sites of the Mexican Central Pacific are presented.

Table S6. - Coverages (\%) of the morphofunctional groups per site. 